\title{
Pleural mesothelioma surveillance: Validity of cases from a tumour registry
}

\author{
France Labrèche $\mathrm{PhD}^{1,2}$, Bruce W Case MD MSc Dipl Occup Hygiene FRCPC ${ }^{3}$, Gaston Ostiguy MD MSc FRCPC 4,5 , \\ Jean Chalaoui MD FRCPC FACR ${ }^{6,7}$, Michel Camus $\mathrm{PhD}^{2,8}$, Jack Siemiatycki $\mathrm{PhD}^{7,9}$
}

\begin{abstract}
F Labrèche, BW Case, G Ostiguy, J Chalaoui, M Camus, J Siemiatycki. Pleural mesothelioma surveillance: Validity of cases from a tumour registry. Can Respir J 2012;19(2):103-108.
\end{abstract}

BACKGROUND: Pleural mesothelioma is a rare tumour associated with exposure to asbestos fibres. Fewer than than one-quarter of cases registered in the Quebec Tumour Registry (QTR) have been compensated as workrelated. While establishing a surveillance system, this led to questioning as to whether there has been over-registration of cases that are not authentic pleural mesotheliomas in the QTR.

OBJECTIVE: To assess whether registered cases of pleural mesothelioma could be confirmed.

METHODS: A medical chart review was designed to assess the proportion of mesothelioma cases newly registered in the QTR in 2001/2002 that could be confirmed. For each registered case, clinical, medical imaging and pathology information were sought and, occasionally, additional immunohistochemistry staining was obtained. Three specialists - a chest physician, a radiologist and a pathologist - reviewed the available information and material, coding each mesothelioma case as to degree of certainty of the mesothelioma diagnosis.

RESULTS: The QTR reported 190 incident cases of mesothelioma (81\% males) for the period. The specialists classified $81 \%$ of charts as 'certain/ probable'or 'possible' mesotheliomas, $8 \%$ as 'unlikely to be a mesothelioma' and $11 \%$ as 'not a mesothelioma'. After excluding chart summaries of unsatisfactory quality, $87 \%$ to $88 \%$ of the charts were classified as 'certain/ probable' or 'possible' mesotheliomas, and $9 \%$ to $11 \%$ were still considered 'not a mesothelioma'.

CONCLUSION: Tumour registry data are a valid source of information for mesothelioma surveillance. While there is some over-registration of mesothelioma cases in the QTR, a significant majority of registered cases appeared to be authentic. Over-registration cannot explain the greater proportion of cases that were not compensated.

Key Words: Asbestos-related lung disease; Medical chart review; Pleural mesothelioma; Surveillance

M alignant pleural mesothelioma is a rare tumour that is often of occupational etiology. Recent estimates of the fraction of mesothelioma deaths attributable to asbestos exposure in men range from $52 \%$ for occupational exposures (1) to $97 \%$ for both occupational and paraoccupational exposures (2). Mesothelioma has a long latency period (usually 20 to 50 years), which may explain why its incidence is still increasing in several countries despite the decrease in asbestos use in most countries over the past 30 years (3-6).

The evolution of mesothelioma incidence and mortality rates is monitored in several countries with surveillance programs based on voluntary reporting $(7,8)$ or with tumour registry data $(5,6)$. Occupational compensation statistics, although readily available, appear to greatly underestimate the actual number of cases, even in Canada where mesothelioma is a reportable disease. A recent study showed that mesothelioma cases

\section{Surveillance du mésothéliome pleural : la validité des cas tirés d'un fichier des tumeurs}

CONTEXTE : Le mésothéliome pleural est une tumeur rare associée à l'exposition aux fibres d'amiante. Moins du quart des cas inscrits dans le Fichier des tumeurs du Québec (FTQ) ont été indemnisés comme maladie professionnelle. Dans le cadre de la mise sur pied d'un système de surveillance, ceci a soulevé la possibilité d'une surinscription de cas n'étant pas réellement des mésothéliomes pleuraux dans le FTQ.

OBJECTIF : Vérifier la validité des cas mésothéliome pleural inscrits dans le fichier.

MÉTHODOLOGIE : Une revue des dossiers médicaux a été effectuée pour évaluer la proportion de cas de mésothéliome nouvellement inscrits dans le FTQ en 2001-2002 qui pouvaient être confirmés. Pour chaque cas inscrit, les chercheurs ont recueilli l'information clinique, les données d'imagerie médicale et les renseignements pathologiques et ont parfois obtenu des colorations immunohistochimiques supplémentaires. Trois spécialistes, soit un pneumologue, un radiologue et un pathologiste, ont analysé l'information et le matériel disponibles et ont codé chaque cas de mésothéliome d'après le degré de certitude du diagnostic.

RÉSULTATS : Le FTQ a recensé 190 nouveaux cas de mésothéliome (81 \% de sexe masculin) pendant la période. Les spécialistes ont classé $81 \%$ des dossiers comme des mésothéliomes « certains/probables » ou « possibles », $8 \%$ comme « mésothéliome improbable » et $11 \%$ comme «pas un mésothéliome ». Après avoir exclu les résumés de dossiers de qualité insatisfaisante, $87 \%$ à $88 \%$ des dossiers ont été classés comme des mésothéliomes " certains/probables " ou "possibles ", et de $9 \%$ à $11 \%$ étaient encore considérés comme "pas un mésothéliome ».

CONCLUSION : Les données du fichier des tumeurs constituent une source valide d'information pour la surveillance des mésothéliomes. On constate une certaine surinscription des cas de mésothéliome dans le FTQ, mais une majorité importante des cas inscrits semblent authentiques. La surinscription ne peut expliquer la plus forte proportion de cas qui n'ont pas été indemnisés.

compensated in British Columbia between 1970 and 2005 constituted $33 \%$ of the number of cases found in the provincial tumour registry around the same dates (9). Slightly higher proportions were reported in Alberta (42\% [10]) and in Ontario (43\% [11]). Several factors may explain the discrepancies between compensated numbers and tumour registry data. A sizeable fraction of deserving, occupationally related mesotheliomas may not be submitted to or recognized by the occupational disease compensation system, and/or a sizeable fraction of cases registered in the tumour registry may not truly be pleural mesotheliomas. Given the relative difficulty of diagnosing mesothelioma (12), both under- and overdiagnosis are distinct possibilities. The present study was undertaken to assess the hypothesis of over-registration of pleural mesotheliomas using the Quebec Tumour Registry (QTR) as a case in point. The available data did not permit an estimate of under-registration.

${ }^{1}$ Institut national de santé publique du Québec; ${ }^{2}$ Département de santé environnementale et santé au travail, Faculté de Médecine, Université de

Montréal; ${ }^{3}$ Department of Pathology, Faculty of Medicine, McGill University; ${ }^{4} \mathrm{McGill}$ University Health Centre - Montreal Chest Institute;

${ }^{5}$ Faculty of Medicine, McGill University; ${ }^{6}$ Centre hospitalier de l'Université de Montréal - Hôpital Notre-Dame; ${ }^{7}$ Faculté de médecine,

Université de Montréal, Montréal, Québec; ${ }^{8}$ Population Health Division, Health Canada, Ottawa, Ontario; ${ }^{9}$ Centre de recherche du Centre

hospitalier de l'Université de Montréal, Montréal, Québec

Correspondence: Dr France Labrèche, Institut de recherche Robert-Sauvé en santé et en sécurité du travail, 505 boulevard de Maisonneuve Ouest,

Montréal, Québec H3A 3C2. Telephone 514-288-1551 ext 278, fax 514-288-6097, e-mail france.labreche@irsst.qc.ca 


\section{METHODS}

During the planning steps of a mesothelioma surveillance system, it had been suggested that 'false positives' in the linked data source - registered cases of mesothelioma - could be responsible for an overestimation of authentic cases, resulting in an apparent undercompensation not based in reality. To address this, a clinical validation study was undertaken to estimate the proportion of pleural mesothelioma cases identified through the QTR that could be confirmed by an expert review of all available clinical, imaging and pathology information.

The research protocol was reviewed by the Research Ethics Committee of the Centre hospitalier de l'Université de Montréal (CHUM) (Montreal, Quebec) and by the Commission d'accès à l'information $d u$ Québec, the body responsible for granting access to governmental data. Each hospital's director of professional services or research ethics committee granted permission to access medical charts. Finally, written consent for access to histological slides and tissue blocks, $\mathrm{x}$-ray films and other imaging studies, such as computed tomography scans, was sought from each patient's family.

\section{Sources of data}

All cases of pleural mesothelioma (International Classification of Diseases, Ninth Revision [ICD-9] codes 163.0 to 163.9 with morphology codes M905x) newly diagnosed between January 1, 2001 and December 31, 2002, throughout the province were identified in the tumour registry. There were 190 such cases diagnosed in 57 hospitals. Medical chart summaries were prepared for all cases, including information regarding contacts (patient and family), sex, date of birth, history of signs and symptoms, hospitalization dates, photocopies of pathology, medical imaging and surgery reports, together with respirology, pathology or oncology consultations.

\section{Chart reviews}

The chart summaries and the medical imaging material were reviewed by a respirologist $(\mathrm{GO})$ and by a radiologist (JC) during joint working sessions to reach a common first revised diagnosis (the "clinico-radiological review'). Available slides and tissues were reviewed by a pathologist (BC) who requested additional immunohistochemical tests if deemed necessary to obtain a first revised diagnosis, based solely on the available pathological material and pathology reports (the 'pathological review'). A final review was performed, making use of both the chart summaries and the pathology material, during joint working sessions in which the three specialists reached a consensus diagnosis (the 'final consensus review').

Verification of a diagnosis for surveillance purposes does not require a single definitive 'gold standard' diagnostic criterion for mesothelioma. Thus, it was decided to use the final consensus review as the reference because the goal was to reproduce the clinical behaviour that resulted in these cases being registered in the QTR as pleural mesotheliomas. In the present study, guidelines recommended by the International Mesothelioma Interest Group (IMIG) as a practical reference for a pathological diagnosis of malignant mesothelioma (12) were applied, but some were not applicable in cases for which no pathological material was available.

\section{Revised diagnostic categories}

The following diagnostic categories were assigned:

- 'definite/probable' (no doubt or very little that it was a mesothelioma);

- 'possible' (compatible clinical information, but some missing or inconclusive information);

- 'unlikely' (incompatible clinical information, but some missing or inconclusive information);

- 'not a mesothelioma' (clear pathological data or other clinical information confirming another type of cancer); and

- 'impossible to classify' (nonspecific or unsatisfactory clinical information, incomplete chart summary, missing reports, etc).

\section{Variables}

The date of diagnosis was extracted from the tumour registry. Survival from date of diagnosis was computed as the number of months between date of diagnosis and date of death, the latter being noted in the medical chart for most patients. The date of death for 57 patients was obtained from the Quebec Death Registry.

\section{Satisfactory data}

The respirologist and the radiologist considered a chart summary to be satisfactory when it contained sufficient details on signs and symptoms, and when $\mathrm{x}$-rays, scans and pathology reports were available, as well as consultation reports in respirology, surgery or oncology. The pathologist considered the pathology data satisfactory when there was sufficient tissue to make an unequivocal diagnosis based on histology and when adequate immunohistochemical markers had been used two markers generally positive for mesothelial cell origin (eg, calretinin and $\mathrm{CK}$ 5/6) and two markers generally negative in mesothelioma but positive in the principal differential diagnoses (eg, carcinoembryonic antigen and thyroid transcription factor-1), as recommended by the IMIG (12). When no pathological material was available, pathological data were considered to be satisfactory if the pathology report was sufficiently detailed and reported on adequate immunohistochemical tests.

\section{Data analysis}

The proportions of registered cases that were confirmed were estimated for the entire series and for subgroups with different characteristics. The analysis was essentially descriptive. To adjust for the fact that the three specialists only had access to chart summaries instead of the complete medical chart, the proportion of diagnostic confirmation of the tumour registry mesothelioma diagnosis on subgroups of cases whose material was considered satisfactory by the specialists was recalculated.

Sensitivity of the results was determined by additional analyses of predictors of diagnostic confirmation, of correspondence between the diagnosis made during the pathological review and the diagnosis made during the clinicoradiological review, and of the respective influence of the pathologist and of the respirologist/radiologist team on the final consensus diagnosis.

\section{RESULTS}

During 2001 and 2002, 190 cases of pleural mesothelioma were registered in the QTR; of these, 187 medical charts were accessible (one was diagnosed outside Quebec and two charts could not be located). A valid address was found for 153 of the 187 patients, and $78 \%$ of the 153 families agreed to grant access to pathological slides and paraffin blocks, and to medical imaging material (films and digital images). Absence of consent thus implied that only the medical chart summary was available for review whereas with consent, the three specialists also had access to the pathological material, together with the $\mathrm{x}$-ray films and other imaging data.

\section{Case descriptions}

Table 1 summarizes the available patient data, $81 \%$ were men. Pathology material was available for 104 patients and pathology reports only for 52 additional patients, resulting in available pathological data for $83 \%$ of all pleural mesothelioma patients. Imaging studies were available for $53 \%$ of patients, but at least one radiology report was available for each patient (data not shown). The percentage of medical charts with mention of the following information was as follows: occupation $-86 \%$; asking about asbestos exposure $-64 \%$; and possible referral for compensation $-40 \%$.

Table 2 summarizes selected patient characteristics, together with their signs and symptoms. Average survival was less than 16 months, and seven patients survived more than five years (four of the seven were confirmed cases [data not shown]). Signs and symptoms that prompted patients to seek medical care were mostly dyspnea and thoracic pain. 
TABLE 1

Available data for cases of pleural mesothelioma*, Quebec, 2001 to 2002

\begin{tabular}{lccc}
\hline & Men & Women & Total \\
\hline Available charts & $152(81.3)$ & $35(18.7)$ & $187(100.0)$ \\
Autopsy performed & $21(13.8)$ & $2(5.7)$ & $23(12.3)$ \\
$\quad$ Autopsy report available ${ }^{\dagger}$ & $14(66.7)$ & $2(100.0)$ & $16(69.6)$ \\
Biopsy performed & $127(83.5)$ & $32(91.4)$ & $159(85.0)$ \\
$\quad$ Slides/tissue blocks available ${ }^{\ddagger}$ & $82(64.6)$ & $22(68.7)$ & $104(65.4)$ \\
$\quad$ Pathology report only & $42(33.1)$ & $10(31.2)$ & $52(32.7)$ \\
Only cytology performed & $18(11.8)$ & $3(8.6)$ & $21(11.2)$ \\
No mention of biopsy/cytology in & $7(4.6)$ & $0(0.0)$ & $7(3.7)$ \\
$\quad$ chart & & & \\
Medical imaging material & & & \\
$\quad$ Films/compact disks available & $80(52.6)$ & $20(57.1)$ & $100(53.5)$ \\
Information found in medical chart & & & \\
$\quad$ Smoking & $148(97.4)$ & $32(91.4)$ & $180(96.3)$ \\
$\quad$ Job or occupation & $141(92.8)$ & $20(57.1)$ & $161(86.1)$ \\
$\quad$ Mention of asbestos & $106(69.7)$ & $13(37.1)$ & $119(63.6)$ \\
$\quad$ Mention of eligibility to be referred & $70(46.1)$ & $4(11.4)$ & $74(39.6)$
\end{tabular}

for compensation $\$$

Data presented as $n$ (\%). *Pleural mesothelioma charts (International Classification of Diseases, Ninth Revision code 163 with morphology M90509053); ${ }^{\dagger}$ Total number of autopsies as denominator; ${ }^{\ddagger}$ Total number of biopsies as denominator; ${ }^{\$}$ Mention, anywhere in the chart, of asbestos (not necessarily in terms of exposure eg, 'asking about asbestos exposure') or of possible 'reference for compensation'

Proportion of diagnostic confirmation

Table 3 summarizes the proportions of diagnostic confirmation, first for all reviewed chart summaries, then for cases with satisfactory data according to the respirologist/radiologist team and, finally, according to the pathologist. The specialists classified $61.9 \%$ of cases as 'definite/ probable', and $19.3 \%$ as 'possible' mesothelioma. Eleven cases were considered 'impossible to classify' and are described below. The histological subtypes of the 109 'definite/probable' cases of pleural mesothelioma were as follows: $64.2 \%$ were coded as epithelioid mesothelioma (M9052), 18.3\% as biphasic (M9053) and 13.8\% as sarcomatous (M9051).

The proportion of 'definite/probable' cases increased appreciably, from $62 \%$ to $77 \%$, when the analysis was restricted to patients with a satisfactory chart summary, and to $73 \%$ for those with satisfactory pathological data. Specialists' satisfaction with the available material did not change the proportion of cases classified as 'not a mesothelioma', which remained approximately 10\%.
TABLE 2

Description of pleural mesothelioma patients according to sex, Quebec, 2001 to 2002

\begin{tabular}{|c|c|c|c|}
\hline & $\begin{array}{c}\text { Men } \\
(n=152)\end{array}$ & $\begin{array}{c}\text { Women } \\
(n=35)\end{array}$ & $\begin{array}{c}\text { Total } \\
(n=187)\end{array}$ \\
\hline $\begin{array}{l}\text { Age at diagnosis, years, mean } \pm \\
\text { SD }\end{array}$ & $68.1 \pm 10.2$ & $62.7 \pm 13.0$ & $67.1 \pm 10.9$ \\
\hline $\begin{array}{l}\text { Survival after diagnosis, } \\
\text { months, mean } \pm \text { SD }\end{array}$ & $10.5 \pm 14.6$ & $15.7 \pm 19.9$ & $11.5 \pm 15.8$ \\
\hline Survival $>5$ years & $5(3.3)$ & $2(5.7)$ & $7(3.7)$ \\
\hline \multicolumn{4}{|l|}{ Smoking status } \\
\hline Never smoker & $23(15.5)$ & $11(34.4)$ & $34(18.9)$ \\
\hline Exsmoker & $97(65.5)$ & $10(31.2)$ & $107(59.4)$ \\
\hline Smoker & $28(18.9)$ & $11(34.4)$ & $39(21.7)$ \\
\hline Unspecified & $4(-)$ & $3(-)$ & $7(-)$ \\
\hline Tumour in right side & $88(57.9)$ & $18(51.4)$ & $106(56.7)$ \\
\hline Presence of pleural plaques & $51(33.6)$ & $3(8.6)$ & $54(28.9)$ \\
\hline \multicolumn{4}{|l|}{ First signs and symptoms } \\
\hline Dyspnea & $92(60.5)$ & $26(74.3)$ & $118(63.1)$ \\
\hline Thoracic pain & $70(46.1)$ & $21(60.0)$ & $91(48.7)$ \\
\hline Cough & $55(36.2)$ & $10(28.6)$ & $65(34.8)$ \\
\hline Fatigue & $50(32.9)$ & $9(25.7)$ & $59(31.6)$ \\
\hline Weight loss & $41(27.0)$ & $4(11.4)$ & $45(24.1)$ \\
\hline Mesothelioma found unexpectedly & $7(4.6)$ & $2(5.7)$ & $9(4.8)$ \\
\hline
\end{tabular}

Data presented as $n$ (\%) unless otherwise indicated

Sensitivity analyses

A comparison of patient and chart characteristics between charts with a confirmed diagnosis ('definite/probable' and 'possible') and those with an unconfirmed diagnosis ('unlikely' and 'not a mesothelioma') is presented in Table 4. Most characteristics were not associated with the likelihood of diagnostic confirmation. Predictive characterisitics were signs compatible with mesothelioma, pleural taps, and the availability of satisfactory pathological, imaging, biopsy, and surgical information or material. Of note, indexes of exposure to asbestos (pleural plaques and exposure to asbestos as recorded in the charts) were not associated with diagnostic confirmation, which is reassuring given that the specialists correctly did not take into account asbestos exposure in their diagnostic confirmation procedure.

Concordance between the confirmed diagnosis made by the respirologist/radiologist team and the one made by the pathologist was explored for charts that contained at least a pathology report. There was exact correspondence with identical revised diagnostic category for $64.0 \%$ (98 of 153) of charts; 88.2\% (135 of 153) of charts presented concordance within one diagnostic category ('definite/probable' or 'possible' diagnoses; 'unlikely' or 'not a mesothelioma'; and 'impossible

TABLE 3

Proportions of diagnostic confirmation for pleural mesothelioma cases for all chart summaries, for cases with satisfactory data according to the respirologist and the radiologist, and according to the pathologist, Quebec, 2001 to 2002

\begin{tabular}{|c|c|c|c|c|c|c|c|c|c|}
\hline & \multicolumn{3}{|c|}{ All cases } & \multicolumn{6}{|c|}{ Cases with satisfactory data* } \\
\hline & \multicolumn{3}{|c|}{ Consensus among the 3 physicians } & \multicolumn{3}{|c|}{ Respirologist and radiologist } & \multicolumn{3}{|c|}{ Pathologist } \\
\hline & Men & Women & Total & Men & Women & Total & Men & Women & Total \\
\hline Definite/probable & $87(61.3)$ & $22(64.7)$ & $109(61.9)$ & 39 (75.0) & $12(85.7)$ & $51(77.3)$ & $82(72.6)$ & $22(75.9)$ & $104(73.2)$ \\
\hline Unlikely & $12(8.4)$ & $2(5.9)$ & $14(7.9)$ & $1(1.9)$ & $0(-)$ & $1(1.5)$ & $4(3.5)$ & $1(3.4)$ & $5(3.5)$ \\
\hline Not a mesothelioma & $14(9.9)$ & $5(14.7)$ & $19(10.8)$ & $6(11.5)$ & $1(7.1)$ & $7(10.6)$ & $9(8.0)$ & $4(13.8)$ & $13(9.2)$ \\
\hline Impossible to classify & $10(-)$ & $1(-)$ & $11(-)$ & $0(0)$ & $0(0)$ & $0(0)$ & $0(0)$ & $0(0)$ & $0(0)$ \\
\hline
\end{tabular}

Data presented as $n$ (\%). *Data were satisfactory for the respirologist and radiologist when medical imaging material and pathology reports were available together with consultation reports; and for the pathologist when pathological material or a suitable pathology report was available (see the 'Variables' section of the Methods section). Chart summaries deemed 'Impossible to classify' were not considered in the computation of percentages. Denominators are as follows: men n=142; women $n=34$; total $n=176$ 


\begin{tabular}{|c|c|c|c|}
\hline \multirow[b]{2}{*}{ Patient characteristics } & \multicolumn{2}{|c|}{ Diagnosis* } & \multirow[b]{2}{*}{$\mathbf{P}^{\dagger}$} \\
\hline & $\begin{array}{c}\text { Confirmed } \\
(n=143)\end{array}$ & $\begin{array}{c}\text { Unconfirmed } \\
(n=44)\end{array}$ & \\
\hline Female sex & $27(18.9)$ & $8(18.2)$ & 1.00 \\
\hline Survival after diagnosis $\geq 2$ years & $20(14.0)$ & $7(15.9)$ & 0.81 \\
\hline $\begin{array}{l}\text { Signs compatible with } \\
\text { mesothelioma (as noted by the } \\
\text { specialists) }\end{array}$ & $101(70.6)$ & $22(50.0)$ & 0.02 \\
\hline $\begin{array}{l}\text { Compatible symptoms (as noted } \\
\text { by the specialists) }\end{array}$ & $119(83.2)$ & $33(75.0)$ & 0.27 \\
\hline $\begin{array}{l}\text { Pleural plaques (as noted by the } \\
\text { specialists) }\end{array}$ & $36(25.2)$ & $11(25.0)$ & 1.00 \\
\hline $\begin{array}{l}\text { Pleural plaques (as noted in the } \\
\text { chart) }\end{array}$ & $40(28.0)$ & $10(22.7)$ & 0.56 \\
\hline $\begin{array}{l}\text { Natural history (as noted by the } \\
\text { specialists) }\end{array}$ & $8(5.6)$ & $0(0.0)$ & 0.20 \\
\hline $\begin{array}{l}\text { Asbestos exposure (as noted by } \\
\text { the specialists) }\end{array}$ & $52(36.4)$ & $14(31.8)$ & 0.72 \\
\hline At least 1 pleural tap & $140(97.9)$ & $37(84.1)$ & $<0.01$ \\
\hline \multicolumn{4}{|l|}{ Chart summary characteristics } \\
\hline Satisfactory pathological material $\left.\right|^{\ddagger}$ & $124(95.4)$ & $18(78.3)$ & 0.01 \\
\hline $\begin{array}{l}\text { Satisfactory medical imaging and } \\
\text { chart summary }\end{array}$ & $58(40.6)$ & $8(18.2)$ & $<0.01$ \\
\hline Biopsy material or report available & $133(93.0)$ & $23(52.3)$ & $<0.01$ \\
\hline $\begin{array}{l}\text { Pathology consultation report } \\
\text { available }\end{array}$ & $39(27.3)$ & $8(18.2)$ & 0.32 \\
\hline $\begin{array}{l}\text { Respirology consultation report } \\
\text { available }\end{array}$ & $30(21.0)$ & $10(22.7)$ & 0.83 \\
\hline Thoracic surgery report available & $76(53.1)$ & $13(29.5)$ & $<0.01$ \\
\hline Autopsy report available & $15(10.5)$ & $5(11.4)$ & 1.00 \\
\hline CT scan report available & $110(76.9)$ & $34(77.3)$ & 1.00 \\
\hline Standard $\mathrm{x}$-ray report available & $120(83.9)$ & $38(86.4)$ & 0.84 \\
\hline
\end{tabular}

*Confirmed diagnosis: 'definite/probable' and 'possible' consensus diagnoses, unconfirmed diagnosis: 'unlikely' and 'not a mesothelioma'; 'Bidirectional Fisher's exact test (bolded values denote statistical significance); ${ }^{\ddagger}$ Smaller denominators: confirmed diagnoses, $n=130$, unconfirmed diagnoses, $n=23$. CT Computed tomography

to classify'); and $78.2 \%$ (79 of 101) of charts fell in one of the two 'certain' diagnostic categories (ie, 'definite/probable' and 'not a mesothelioma' categories). Restricting this analysis to charts with satisfactory pathological data did not change the concordance figures appreciably (data not shown).

The stepwise procedure used to judge diagnostic confirmation (ie, a clinicoradiological review and a pathological review, followed by a final consensus review) enabled an estimation of the respective influence of the medical specialties on the consensus decision regarding diagnostic confirmation. Of the 55 charts for which there was no initial consensus, the final consensus decision was that of the pathologist for 29 charts (53\%), that of the respirologist/radiologist team for 20 charts $(36 \%)$ and an intermediary diagnosis for the remaining six charts $(11 \%)$.

\section{'Impossible to classify' cases}

Eleven cases were considered 'impossible to classify' (10 men). On average, they were older than the other subjects ( 78.5 years of age versus 66.4 years of age). Their chart summaries were considered unsatisfactory for several reasons: medical imaging was not available for six cases and no intervention (not even a pleural tap) was performed for two of them (who were quite sick and suffered from cognitive impairment). Two patients were referred from another hospital and the investigation results were absent from their medical chart. Finally, only five of these patients had undergone a biopsy and, although slides for three were available, there was insufficient tissue for new immunohistochemical testing.

\section{DISCUSSION}

Characteristics of the 187 pleural mesothelioma cases registered in the QTR in 2001 and 2002 were consistent with known epidemiological features of the disease: higher proportion of men, average age of 67 years at diagnosis, survival of 12 to 18 months after diagnosis and mostly epithelioid histological type $(13,14)$. A clinical and pathological review of chart summaries of these cases resulted in the following reclassification: $143(81 \%)$ definite/probable or possible, $14(8 \%)$ improbable and 19 (11\%) nonmesothelioma cases. Among cases with satisfactory chart summaries and medical imaging or with satisfactory pathological data, a larger proportion of diagnoses were confirmed ( $87 \%$ definite/probable or possible), while the proportion of noncases remained constant.

These results compare favourably with those reported in other validation studies. A few studies published between 1974 and 1995 validated the diagnosis of cases reported to mesothelioma registries in Australia, Europe and the United States, with 33\% to 68\% of cases classified as definite mesotheliomas (15-19). Our corresponding figures range between $62 \%$ and $77 \%$. A study similar to ours compared mesothelioma cases reported to the French National Mesothelioma Network and cases retrieved from administrative data (20). Of 46 charts of patients hospitalized between 1998 and 1999, a mesothelioma diagnosis was maintained for $70 \%$, and four cases were considered unlikely or not a mesothelioma. Results of our study are not quite comparable with those reported in older studies because some were conducted before the routine use of immunohistochemical markers, while others focused on charts of patients with difficult diagnoses. Nevertheless, the QTR appears to be as valid as specialized mesothelioma registries with respect to diagnostic specificity.

'False positives' in the QTR do not explain the gap between registered and compensated cases of pleural mesothelioma. An annual average of 33 cases were compensated in Quebec between 2001 and 2003 (21), merely 60\% of 'definite/probable' pleural mesothelioma cases registered yearly in the tumour registry. Moreover, a number of true pleural mesotheliomas are not registered in the tumour registry. A recent study pairing tumour registry data with compensation data showed that $13 \%$ of compensated cases (whose diagnosis had been verified before ruling on the association with occupational exposure) were coded under another histological type and/or site in the tumour registry (eg, mesothelioma of thymus, heart and mediastinum or lung cancer) between 1975 and 2002 (22). Thus, although the QTR comprises a certain proportion of 'false positive' pleural mesotheliomas, it may still miss at least $10 \%$ to $15 \%$ of 'true' pleural mesotheliomas.

The procedure used in the present validation study was purposefully similar to the actual diagnostic procedure, relying on the opinion of experienced physicians from three complementary specialties (pathology, respirology and radiology) because verification of a diagnosis for surveillance purposes does not require a definitive 'gold standard' diagnosis. The IMIG published detailed guidelines as a practical reference for the pathological diagnosis of mesothelioma, but also specified that pathologists "... should always take the clinical, radiologic, and pathologic features into consideration...” (12).

Despite the fact that chart summaries were not always very detailed, concordance among specialists was good, ranging from $64 \%$ for exact correspondence to $88 \%$ for correspondence within one diagnostic category. Asbestos exposure was not taken into account in the diagnostic attribution, in accordance with guidelines on mesothelioma diagnostic criteria $(12,23)$, as demonstrated by the absence of association between asbestos exposure information and the confirmation of mesothelioma diagnosis (Table 4). The study covered almost all mesothelioma cases diagnosed in Quebec in 2001 and 2002, whereas most 
validation studies were restricted to cases from certain hospitals or to difficult cases.

Regarding the limitations of the present study, access to the medical charts limited to a summary and excerpts could have increased the level of uncertainty in the diagnostic confirmation. We attempted to address this problem with a separate analysis of 'satisfactory' chart summaries. This resulted in larger proportions of confirmations compared with using all chart summaries. It would also have been interesting to estimate under-registration as well as over-registration, but this was not feasible within the scope of the project.

The present project aimed at verifying whether pleural mesothelioma cases registered in the QTR were 'real' cases. The validation comforts us that $62 \%$ to $77 \%$ of registered cases are certain or probable cases, and that an additional $10 \%$ to $19 \%$ are possible cases.

\section{CONCLUSION}

The present study confirmed an important discrepancy between the number of cases of this particular asbestos-related disease and the number of compensated cases. It also confirms the usefulness of the tumour registry as a source of mesothelioma surveillance data.

ACKNOWLEDGEMENTS: This study was funded by the Ministère de la santé et des services sociaux du Québec, through its "Programme de recherche sur les maladies de l'amiante du Québec". The authors thank the patients and families who authorized access to biopsy material and to medical imaging material. They also acknowledge the data acquisition work of Madeleine Ferron, Madeleine Caron and the Radiology Department personnel of the Centre hospitalier de l'Université de Montréal - Hôpital Notre-Dame. They particularly thank the physicians who supported the project in their hospital, namely (in alphabetical order), Drs Raymond Bégin (Centre hospitalier universitaire de Sherbrooke), Christian Couture (Institut universitaire de cardiologie et de pneumologie de Québec), Réal Lagacé (Centre hospitalier universitaire de Québec), Ronald Onerheim (St Mary's Hospital Center) and Michel Rouleau (Centre hospitalier affilié universitaire de Québec - Pavillon l'Enfant-Jésus). JS holds the GuzzoEnvironment-Cancer Research Chair of the Cancer Research Society.

COMPETING INTERESTS: Dr Case has acted as an expert witness for law firms representing defendants and plaintiffs in asbestos litigation and compensation board proceedings, and has been a paid consultant to regulatory agencies and compensation boards in North America. Drs Labrèche, Ostiguy, Chalaoui, Camus and Siemiatycki declare no competing interests.

\section{REFERENCES}

1. Lacourt A, Rolland P, Gramond C, et al. Attributable risk in men in two French case-control studies on mesothelioma and asbestos. Eur J Epidemiol 2010;25:799-806.

2. Rushton L, Bagga S, Bevan R, et al. Occupation and cancer in Britain. Brit J Cancer 2010;102:1428-37.

3. Cree M, Lalji M, Jiang B, Carriere KC, Beach J, Kamruzzaman A. Explaining Alberta's rising mesothelioma rates. Chronic Dis Can 2009;29:144-52.

4. Montanaro F, Bray F, Gennaro V, et al. Pleural mesothelioma incidence in Europe: Evidence of some deceleration in the increasing trends. Cancer Causes Control 2003;14:791-803.

5. Price B, Ware A. Time trend of mesothelioma incidence in the United States and projection of future cases: An update based on SEER data for 1973 through 2005. Crit Rev Toxicol 2009;39:576-88
6. Pukkala E, Martinsen JI, Lynge E, et al. Occupation and cancer follow-up of 15 million people in five Nordic countries. Acta Oncol 2009;48:646-790.

7. Hannaford-Turner K, Elder D, Sim MR, Abramson MJ, Johnson AR, Yates DH. Surveillance of Australian workplace Based Respiratory Events (SABRE) in New South Wales. Occup Med 2010;60:376-82.

8. Le Stang N, Belot A, Gilg Soit Ilg A, et al. Evolution of pleural cancers and malignant pleural mesothelioma incidence in France between 1980 and 2005. Int J Cancer 2010;126:232-8.

9. Kirkham TL, Koehoorn MW, McLeod CB, Demers PA. Surveillance of mesothelioma and workers' compensation in British Columbia, Canada. Occup Environ Med 2011;68:30-5.

10. Cree M, Lalji M, Jiang B, Carriere KC. Under-reporting of compensable mesothelioma in Alberta. Am J Ind Med 2009;52:526-33.

11. Payne JI, Pichora E. Filing for workers' compensation among Ontario cases of mesothelioma. Can Respir J 2009;16:148-52.

12. Husain AN, Colby TV, Ordóñez NG, et al. Guidelines for pathologic diagnosis of malignant mesothelioma: A consensus statement from the International Mesothelioma Interest Group. Arch Pathol Lab Med 2009;133:1317-31.

13. Gilg Soit Ilg A, Goldberg M, Rolland P, et al. Programme national de surveillance du mésothéliome - Principaux résultats 1998-2006. Saint-Maurice (Fra) : Institut de veille sanitaire, 2009. <www.invs. sante.fr/publications/2009/pnsm/pnsm_resultats_1998_2006.pdf> (Accessed June 4, 2011).

14. Safe Work Australia. Mesothelioma in Australia. Incidence 1982 to 2006. Mortality 1997 to 2007. Safe Work Australia, Commonwealth of Australia, 2010. <www.safeworkaustralia.gov.au/ AboutSafeWorkAustralia/WhatWeDo/Publications/Documents/339/ MesotheliomaInAustralia_Incidence1982-2006

Mortality1997-2007_PDF.pdf> (Accessed June 4, 2011).

15. Ferguson DA, Berry G, Jelihovsky T, et al. The Australian mesothelioma surveillance program 1979-1985. Med J Austr 1987;147:166-72.

16. Bignon J, Sebastien P, Di Menza L, Payan H. French mesothelioma register. Ann N Y Acad Sci 1979;330:455-66.

17. Greenberg M, Davies TAL. Mesothelioma register 1967-68. $\mathrm{Br} J$ Ind Med 1974;31:91-104.

18. Andrion A, Magnani C, Betta PG, et al. Malignant mesothelioma of the pleura: Interobserver variability. J Clin Pathol 1995;48:856-60.

19. Spirtas R, Keehn RJ, Beebe GW, et al. Results of a pathology review of recent US mesothelioma cases. Accomplishments Oncol 1986:1:144-52.

20. Geoffroy-Perez B. Confrontation des données du Programme national de surveillance du mésothéliome et du PMSI. Rapport d'étude, Institut de veille sanitaire, France, 2004. <www.invs.sante. $\mathrm{fr} /$ publications/2004/surveillance_mesotheliome/rapport mesotheliome_pmsi.pdf> (Accessed June 4, 2011).

21. De Guire L, Provencher S. Étude des nouveaux cas de maladies professionnelles pulmonaires reliées à l'exposition à l'amiante au Québec : 1988-2003. Direction des Risques biologiques, environnementaux et occupationnels, Institut national de santé publique du Québec, Montréal, 2009. <www.inspq.qc.ca/pdf/ publications/968_MalPulmoAmianteQc1988-2003.pdf> (Accessed June 4, 2011).

22. Lebel G, Gingras S. De Guire L. Jumelage des cas de mésothéliome et d'amiantose reconnus comme maladies professionnelles pulmonaires aux nouveaux cas de cancer et aux hospitalisations avec amiantose. Direction des Risques biologiques, environnementaux et occupationnels, Institut national de santé publique du Québec, Montréal, 2009. <www.inspq.qc.ca/pdf/publications/1002_ JumelageMesoAmian.pdf> (Accessed June 4, 2011).

23. British Thoracic Society Standards of Care Committee. BTS statement on malignant mesothelioma in the UK, 2007. Thorax 2007;62(Suppl 2):ii1-19. 


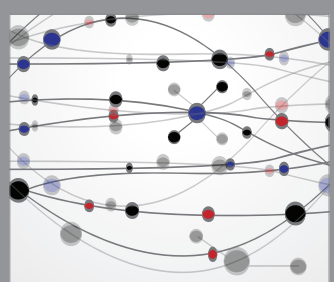

The Scientific World Journal
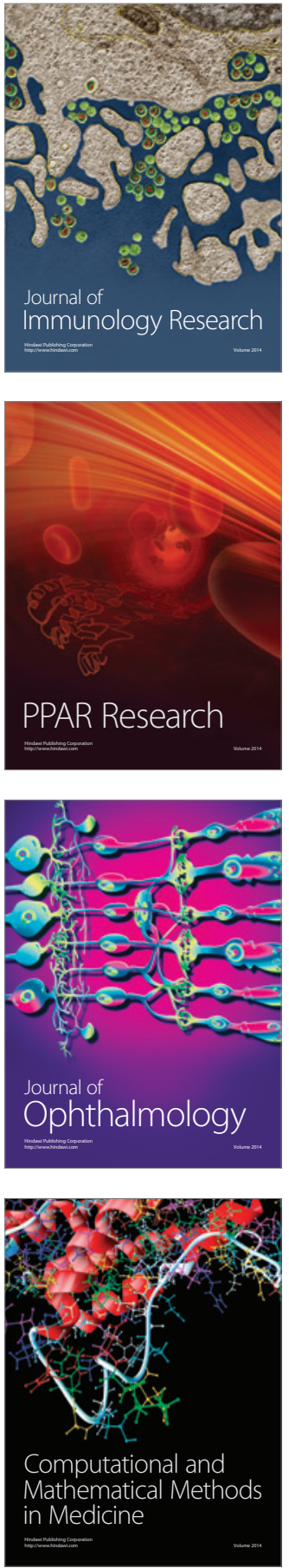

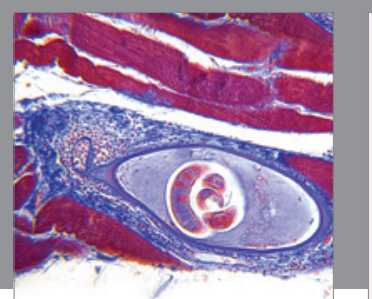

Gastroenterology Research and Practice

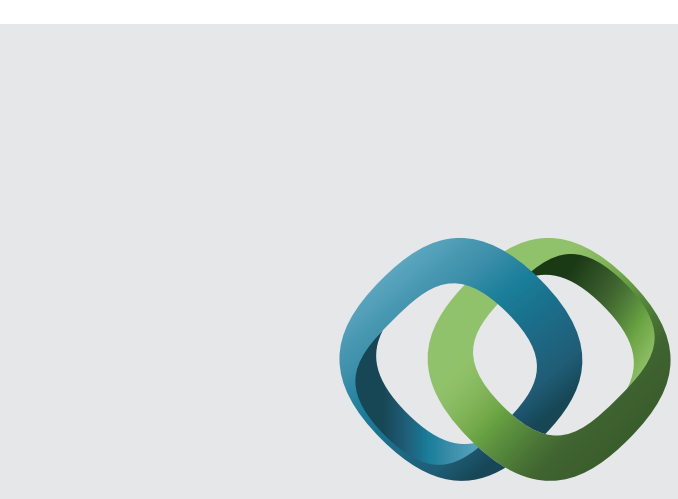

\section{Hindawi}

Submit your manuscripts at

http://www.hindawi.com
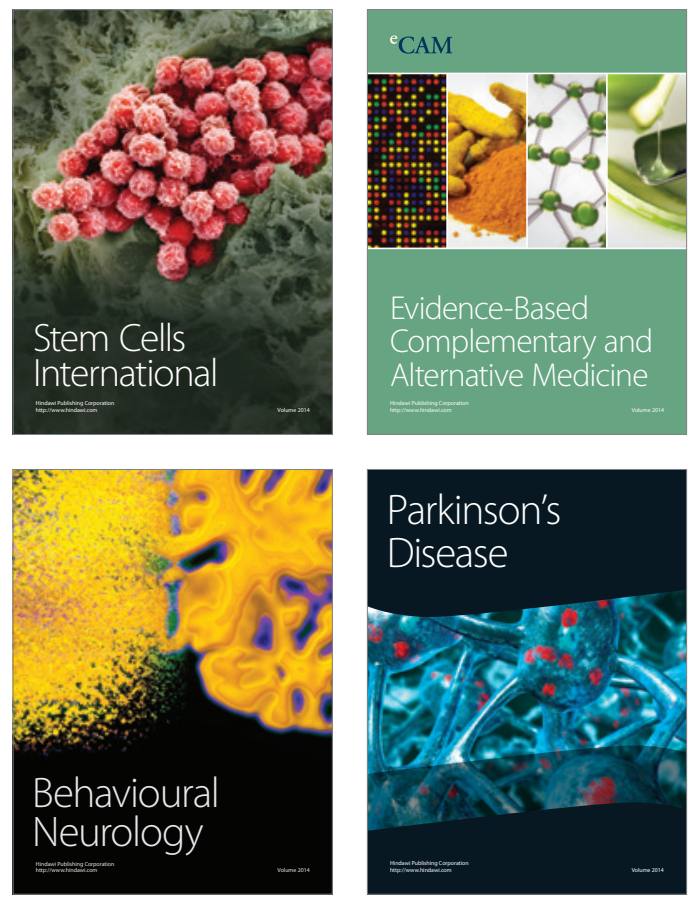
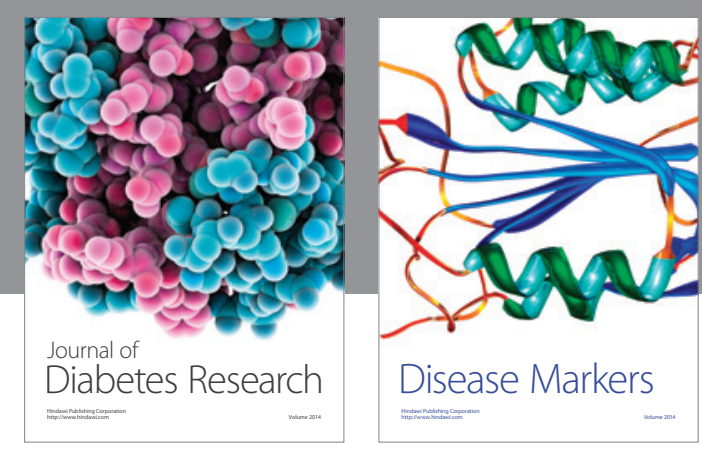

Disease Markers
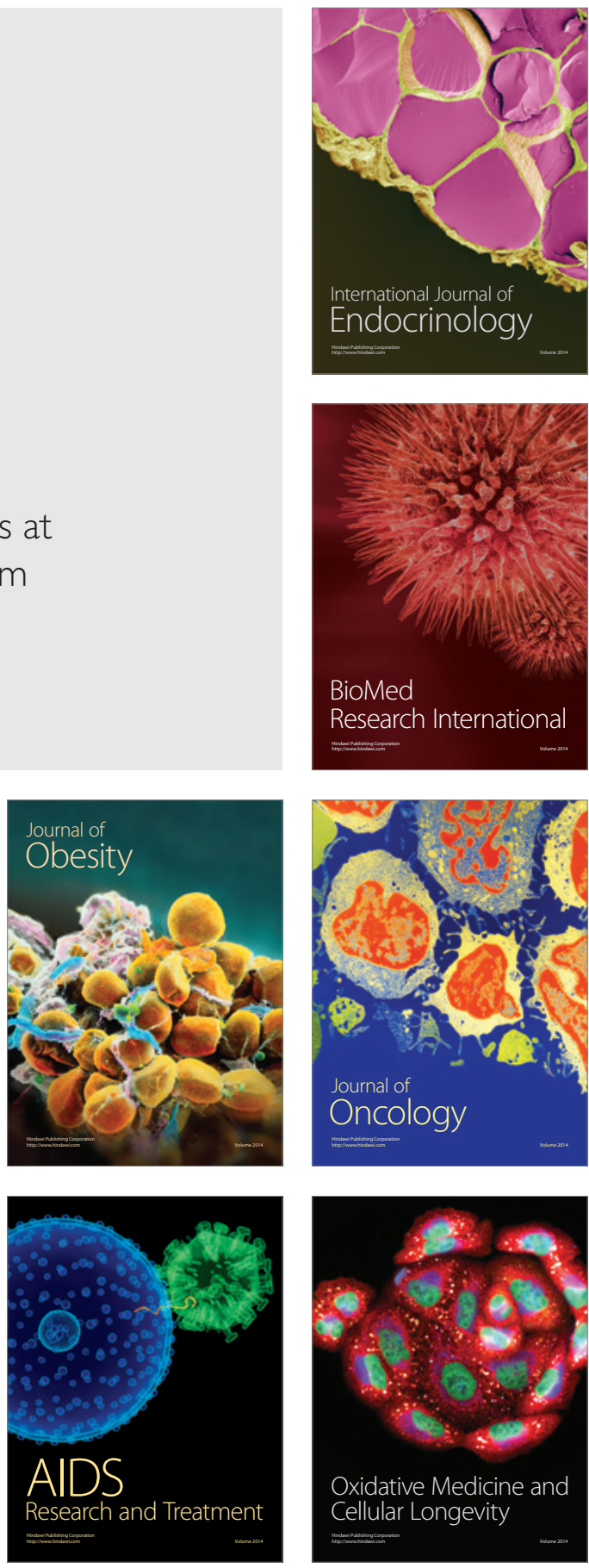